Check for updates

Cite this: RSC Adv., 2018, 8, 38281

Received 4th October 2018

Accepted 1st November 2018

DOI: $10.1039 / \mathrm{c} 8 \mathrm{ra} 08207 \mathrm{c}$

rsc.li/rsc-advances

\section{A convenient one-pot synthesis of $\mathrm{N}$-substituted amidoximes and their application toward 1,2,4- oxadiazol-5-ones $\uparrow$}

\author{
Wong Phakhodee, (iD *ab Chuthamat Duangkamol, ${ }^{a}$ Nitaya Wiriya ${ }^{a}$ \\ and Mookda Pattarawarapan ${ }^{\text {ab }}$
}

\begin{abstract}
The first direct one-pot approach for the synthesis of $\mathrm{N}$-substituted amidoximes from secondary amides or the intermediate amides has been developed. Through the $\mathrm{Ph}_{3} \mathrm{P}-\mathrm{I}_{2}$-mediated dehydrative condensation, a variety of $\mathrm{N}$-aryl and $\mathrm{N}$-alkyl amidoximes $\left(\mathrm{R}^{1}(\mathrm{C}=\mathrm{NOH}) \mathrm{NHR}^{2}\right.$, where $\mathrm{R}^{1}$ or $\mathrm{R}^{2}=$ aryl, alkyl, or benzyl) were readily afforded under mild conditions and short reaction times. The synthetic application of the obtained amidoximes has also been demonstrated through the formation of 1,2,4-oxadiazolones via base-mediated carbonylative cyclization with 1,1'-carbonyldiimidazole.
\end{abstract}

\section{Introduction}

$N$-Substituted amidoximes are privileged structures that have been used extensively as versatile building blocks in the synthesis of various heterocycles such as benzimidazoles, ${ }^{1}$ 4aminoquinazolines, ${ }^{2}$ 1-aminoisoquinolines, ${ }^{3}$ oxadiazoles, ${ }^{4}$ oxadiazolones (thiones), ${ }^{5}$ and triazoles. ${ }^{1 c}$ They also serve as the key intermediates in the synthesis of amidines as well as metal ion chelating ligands in coordination chemistry. ${ }^{6}$ In drug development, various $N$-substituted amidoxime derivatives have been introduced as prodrug candidates to achieve good cell permeability and oral bioavailability. ${ }^{6 a}$ The representative examples are shown in Fig. 1. Epacadostat (A) is currently being studied in a phase 3 clinical trial in patients with unresectable or metastatic melanoma. ${ }^{7} \mathbf{B}$ is a novel inhibitor of indoleamine 2,3dioxygenase. ${ }^{8} \mathbf{C}$ and $\mathbf{D}$ are potent inhibitors of Escherichia coli RNA polymerase. ${ }^{9}$ Oseltamivir prodrug $\mathbf{E}$ has been developed as an anti-influenza agent with favourable pharmacokinetics. ${ }^{10}$

Despite their essential applications, only a limited number of synthetic routes for $N$-substituted amidoximes has been reported in the literature. Whereas the synthesis of unsubstituted amidoximes starting from benzonitriles is well-established, ${ }^{6} \boldsymbol{a}$ the synthesis of $\mathrm{N}$-substituted amidoximes is much less straightforward requiring laborious multistep procedures.

One of the most commonly used methods involves the reaction of amines with $N$-hydroxyimidoyl chloride $(\mathbf{I}){ }^{11}$ However, I is not readily available and has to be prepared in two

${ }^{a}$ Department of Chemistry, Faculty of Science, Chiang Mai University, Chiang Mai 50200, Thailand. E-mail: wongp2577@gmail.com

${ }^{b}$ Research Center on Chemistry for Development of Health Promoting Products from Northern Resources, Chiang Mai University, Chiang Mai, 50200, Thailand

$\dagger$ Electronic supplementary information (ESI) available. See DOI: $10.1039 / \mathrm{c} 8 \mathrm{ra} 08207 \mathrm{c}$ steps starting from condensation of aldehydes with hydroxylamine hydrochloride, followed by chlorination of the formed oximes with $\mathrm{N}$-chlorosuccinimide ${ }^{\mathbf{1 2}}$ or chlorine gas. ${ }^{5 c}$ Moreover, the protocol is ineffective for preparing aliphatic imidoyl chlorides as the starting aldehydes are less reactive. Aliphatic imidoyl chlorides are also highly unstable and are often obtained in low yields. ${ }^{12,13}$

Alternatively, $\mathrm{N}$-substituted amidoximes could be synthesized via the addition of hydroxylamine or its analogs to the activated amide derivatives such as imidoyl chloride (II) derived from dehydrative chlorination of secondary amide with $\mathrm{PCl}_{5}$ or $\mathrm{P}_{2} \mathrm{O}_{5},{ }^{14}$ thioamide (III) from treatment of the starting amides with Lawesson's reagent ( $p$-methoxyphenylthionophosphine sulphide dimer) ${ }^{\mathbf{1 5}}$ or imidoylbenzotriazole (IV) from the reaction of an amide with oxalyl chloride and benzotriazole. ${ }^{16}$ Other methods include hydrolysis of $1,2,4$-oxadiazolones $(\mathbf{V}),{ }^{17}$ or the reaction of primary nitroalkanes (VI) with amines ${ }^{\mathbf{1 8}}$ or lithium amides. ${ }^{19}$ However, these approaches suffer from various limitations such as the use of highly toxic reagents, multistep synthesis with tedious work-up and purification, harsh reaction conditions, long reaction times, low yields, and limit substrate scope. Therefore, the development of general and practical one-

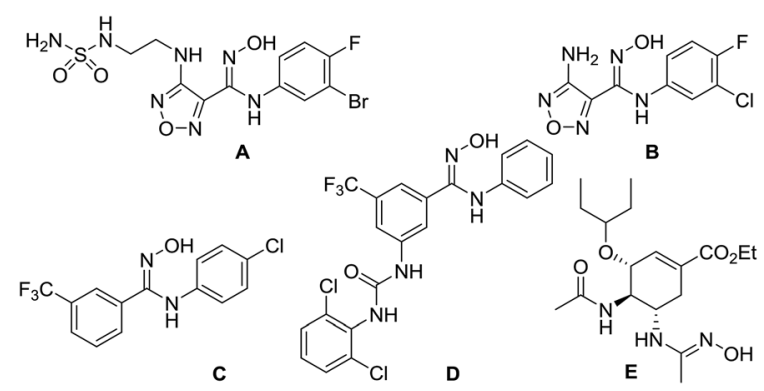

Fig. 1 Examples of bioactive $N$-substituted amidoximes. 


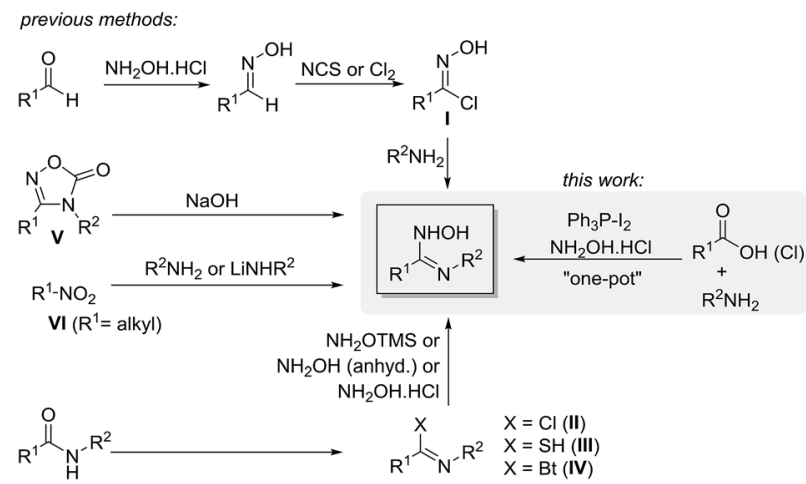

Scheme 1 Synthetic approaches toward $N$-substituted amidoximes.

pot approaches to access a variety of amidoximes derivatives from readily available precursors is still desirable.

In the recent years, iodine-mediated organic synthesis has attracted considerable attention. ${ }^{20}$ This could be attributed to its inexpensiveness, green nature, and high efficiency in promoting a range of reactions. In particular, the combination of iodine with triphenylphosphine $\left(\mathrm{Ph}_{3} \mathrm{P}\right)$ provides a highly effective dehydrating agent leading to rapid and high yielding synthesis under mild reaction conditions. ${ }^{21}$ In a continuation of our interest in developing facile one-pot methods using the $\mathrm{Ph}_{3} \mathrm{P}-\mathrm{I}_{2}$ combination, ${ }^{22}$ we have designed a one-pot approach for the synthesis of $\mathrm{N}$-substituted amidoximes which enables the use of inexpensive and commercially available secondary amides, acid chlorides or carboxylic acids as the key precursors (Scheme 1). Herein, we wish to report our detailed study in this aspect.

\section{Results and discussion}

We started our investigations by optimizing the reaction of $\mathrm{N}$ phenylbenzamide (1a) with hydroxylamine hydrochloride. Typically, the reaction was carried out by addition of $N$-phenylbenzamide (1 equiv.) into a mixture of $\mathrm{Ph}_{3} \mathrm{P}$ (1.5 equiv.) and halogenated additive (1.5 equiv.) in freshly dry dichloromethane, followed by addition of base (5 equiv.) and hydroxylamine hydrochloride (1.5 equiv.).

As shown in Table 1, among the tested organic bases, only triethylamine gave rise to the formation of the desired product 2a in high yield (entries 1-6). The reaction in the presence of the commonly used imidazole gave the product in low yield (entry 4). Using diisopropylethylamine (DIPEA) although led to increase conversion to the product (entry 5), the reaction was incomplete even after $24 \mathrm{~h}$. According to entries 7-9, the reaction did not proceed when replacing iodine with other halogenated additives such as $\mathrm{N}$-chlorosuccinimide (NCS), $\mathrm{N}$ bromosuccinimide (NBS), or carbon tetrabromide $\left(\mathrm{CBr}_{4}\right)$. In addition, no conversion was observed when the reaction was carried out in the absence of $\mathrm{Ph}_{3} \mathrm{P}$ (entry 10) indicating that phosphonium iodide or triphenylphosphoranediiodide are acting as the key activating species. It should be noted also that the reaction did not proceed when using oxalyl chloride or thionyl chloride as the dehydrating agent.
Table 1 Optimization of the reaction conditions ${ }^{a}$

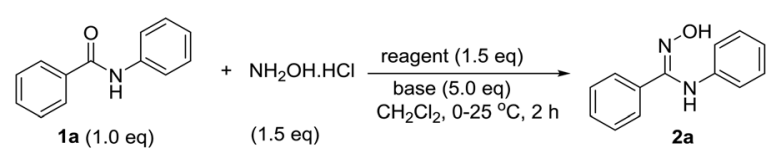

\begin{tabular}{|c|c|c|c|}
\hline Entry & Reagent & Base & Yield (\%) \\
\hline 1 & $\mathrm{I}_{2} / \mathrm{Ph}_{3} \mathrm{P}$ & DABCO & $\mathrm{nr}$ \\
\hline 2 & $\mathrm{I}_{2} / \mathrm{Ph}_{3} \mathrm{P}$ & DBU & Trace \\
\hline 3 & $\mathrm{I}_{2} / \mathrm{Ph}_{3} \mathrm{P}$ & NMM & 10 \\
\hline 4 & $\mathrm{I}_{2} / \mathrm{Ph}_{3} \mathrm{P}$ & Imidazole & 20 \\
\hline 5 & $\mathrm{I}_{2} / \mathrm{Ph}_{3} \mathrm{P}$ & DIPEA & 45 \\
\hline 6 & $\mathrm{I}_{2} / \mathrm{Ph}_{3} \mathrm{P}$ & $\mathrm{Et}_{3} \mathrm{~N}$ & 85 \\
\hline 7 & $\mathrm{NCS} / \mathrm{Ph}_{3} \mathrm{P}$ & $\mathrm{Et}_{3} \mathrm{~N}$ & $\mathrm{nr}$ \\
\hline 8 & $\mathrm{NBS} / \mathrm{Ph}_{3} \mathrm{P}$ & $\mathrm{Et}_{3} \mathrm{~N}$ & $\mathrm{nr}$ \\
\hline 9 & $\mathrm{CBr}_{4} / \mathrm{Ph}_{3} \mathrm{P}$ & $\mathrm{Et}_{3} \mathrm{~N}$ & $\mathrm{nr}$ \\
\hline 10 & $\mathrm{I}_{2}$ & $\mathrm{Et}_{3} \mathrm{~N}$ & $\mathrm{nr}$ \\
\hline
\end{tabular}

${ }^{a}$ Reaction conditions: $N$-phenylbenzamide $(0.28 \mathrm{mmol})$, hydroxylamine hydrochloride $(0.42 \mathrm{mmol}), \mathrm{Ph}_{3} \mathrm{P}(0.42 \mathrm{mmol})$, additive $(0.42 \mathrm{mmol})$, base $(1.4 \mathrm{mmol}), \mathrm{CH}_{2} \mathrm{Cl}_{2}(2 \mathrm{~mL}), 0{ }^{\circ} \mathrm{C}-\mathrm{RT}, 2 \mathrm{~h} . \mathrm{nr}=$ no reaction.

With the optimized reaction conditions in hand, the scope and generality of the reaction were studied. For this purpose, the reactions of diverse $N$-substituted aromatic and aliphatic amides were investigated, and the results are shown in Scheme 2. N-Aryl substituted secondary amides bearing either an electron-donating group (EDG), such as methyl or methoxy, or an electron-withdrawing group (EWG), such as chloro, bromo, or nitro on the $N$-phenyl ring underwent smooth conversion to give 2a-2e in high yields. However, the electronic effect of the 4nitro group in the aromatic ring of $\mathrm{R}^{1}$ of amide $\mathbf{1}$ seems to lower the yield of $\mathbf{2 f}$. The condition is applicable to substrate bearing heterocyclic ring although slightly lower yield of the product $2 \mathrm{~g}$ was obtained due to the difficulty in the product isolation.

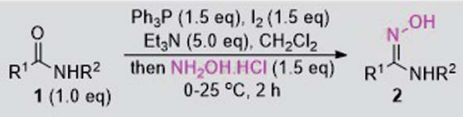

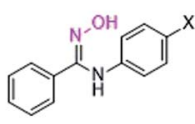

$$
\begin{aligned}
& \text { 2a, } X=\mathrm{H}(85 \%) \\
& \text { 2b, } X=\mathrm{Me}(76 \%) \\
& \text { 2c, } X=\mathrm{OMe}(75 \%) \\
& \text { 2d, } X=\mathrm{Br}(77 \%)
\end{aligned}
$$
2e, $X=\mathrm{NO}_{2}(80 \%)$
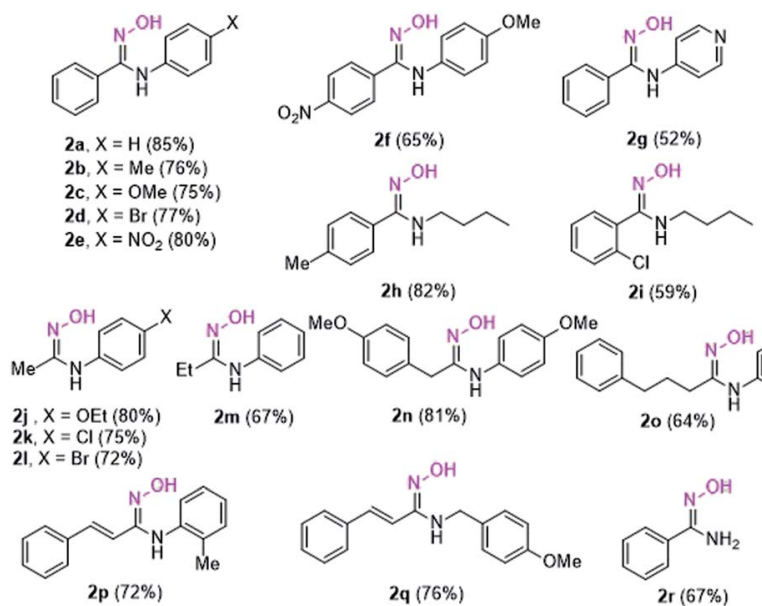

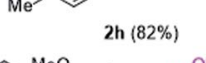
2i (59\%)
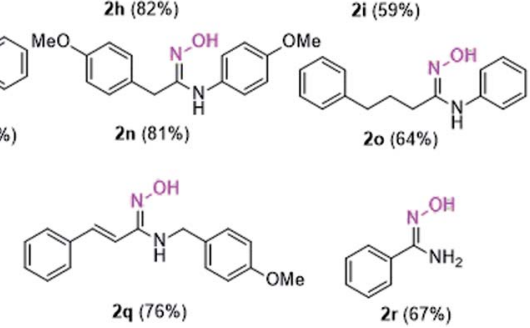

Scheme 2 Synthesis of $\mathrm{N}$-substituted amidoximes 2 starting from amides. 
$\mathrm{N}$-Alkyl substituted amides were also converted into the corresponding amidoximes $\mathbf{2 h} \mathbf{- 2} \mathbf{i}$ in satisfactory yields. Unlike other reported procedures which are not suitable for preparation of amidoximes with $\mathrm{R}^{1}=$ alkyl, ${ }^{12,13}$ our conditions enable the synthesis of various acetimidamide derivatives such as $\mathbf{2 j}-\mathbf{2} \mathbf{l}$ from $N$-arylacetamide substrates without any difficulty. Other secondary amides having $\mathrm{R}^{1}=$ ethyl, benzyl, or even long alkyl chain also provided the products $\mathbf{2 m - 2 o}$ in moderate to high yields. Additionally, the reaction condition is applicable with amides bearing $\alpha, \beta$-unsaturated moiety. The exclusive formation of amidoximes $\mathbf{2 p}$ and $\mathbf{2 q}$ indicated no complication due to Michael addition to the $\alpha, \beta$-unsaturated system. The presence of steric ortho-substituted methyl group did not affect the reaction (see compound $2 \mathbf{p}$ ). It should be noted that primary amide is also a viable substrate as illustrated in the synthesis of compound 2r. However, the reactions with tertiary amides such as $N, N$-dimethylbenzamide or $N$-benzoylpiperidine failed to give the amidoxime products (data not shown).

With the success in the formation of $N$-substituted amidoximes from amide substrates, we thus further investigated a direct one-pot reaction toward amidoximes using acid chlorides or carboxylic acids as the amide precursors. According to Scheme 3, condensation of amines with acid chlorides led to an in situ formation of amides which could then be activated with $\mathrm{Ph}_{3} \mathrm{P}-\mathrm{I}_{2}$ before treatment with hydroxylamine hydrochloride. The reaction using benzoyl chloride gave rise to various amidoximes having $\mathrm{N}$-aryl or $\mathrm{N}$-alkyl substituent in moderate to good yields.

Due to the remarkable difference in the reactivity of carboxylic acid and amide, it was envisioned that a direct onepot synthesis of amidoximes from carboxylic acids via intermediate amides would be possible through a sequential addition of an amine, then hydroxylamine hydrochloride to a carboxylic acid in the presence of an excessive amount of dehydrating agent.

To our delight, the procedure enables the synthesis of various $N$-substituted amidoximes in moderate to good yields (Scheme 3). No complication from the formation of amidine side-product was observed. This one-pot three-component coupling led to an improve in the efficiency of the reaction avoiding laborious separation and purification of the amide intermediate.

Based on the obtained results and our previous experiences in the $\mathrm{Ph}_{3} \mathrm{P}-\mathrm{I}_{2}$-mediated synthesis, the mechanism for the formation of $\mathrm{N}$-substituted amidoximes was proposed as shown in Scheme 4. The combination of $\mathrm{Ph}_{3} \mathrm{P}$ with $\mathrm{I}_{2}$ provides

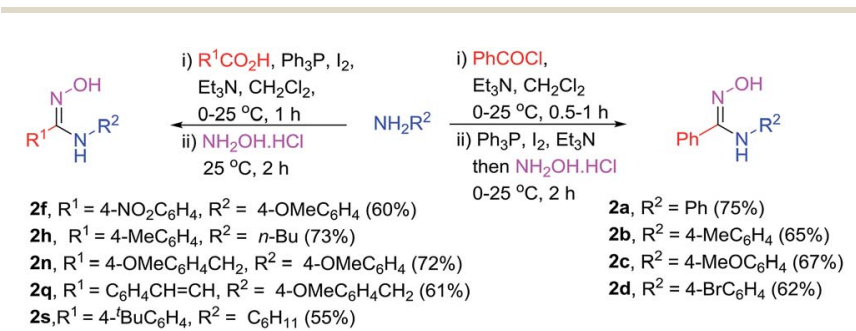

Scheme 3 Synthesis of $N$-substituted amidoximes through in situ formation of amides.

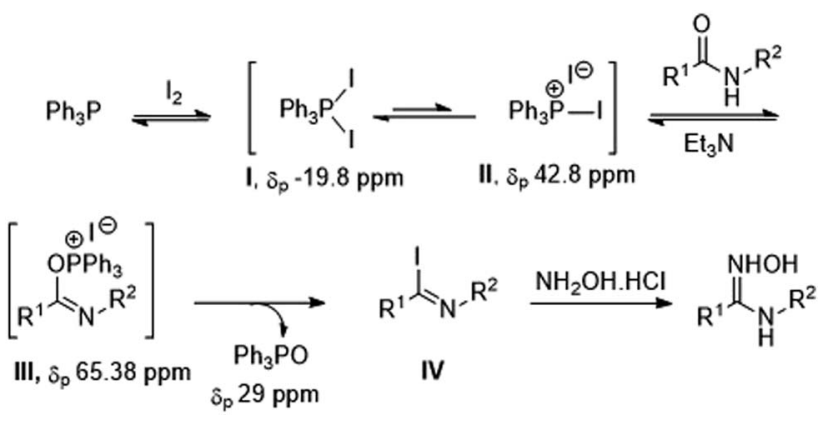

Scheme 4 Proposed mechanism for the $\mathrm{Ph}_{3} \mathrm{P}-\mathrm{I}_{2}$ mediated synthesis of $\mathrm{N}$-substituted amidoxime.

triphenylphosphoranediiodide I and triphenylphosphonium iodide II. Upon additon of an amide and base, phosphorylation at the oxygen atom of the amide then leads to the formation of imidinium intermediate III. This species could be converted into another reactive intermediate, imidoyl iodide IV. Displacement of III or IV with hydroxylamine hydrochloride then gives rise to $\mathrm{N}$-substituted amidoxime.

To obtain scientific evidences regarding the mechanism of the process, ${ }^{31} \mathrm{P}\left\{{ }^{1} \mathrm{H}\right\}$ NMR spectroscopy was used to monitor the progress of the reaction of $N$-phenylbenzamide. As shown in Scheme 4 and Fig. $\mathrm{S} 1$ (ESI $\dagger$ ), addition of $\mathrm{Ph}_{3} \mathrm{P}$ to the deuterated chloroform solution of $\mathrm{I}_{2}$ resulted in an appearance of a resonance peak at $-19.8 \mathrm{ppm}$ corresponded to phosphoranediiodide species $\mathbf{I} .{ }^{23}$ No significant change in the ${ }^{31} \mathrm{P}\left\{{ }^{1} \mathrm{H}\right\}$ NMR spectrum was observed after adding $N$-phenylbenzamide except that a small signal appeared at $42.8 \mathrm{ppm}$. This signal could be attributed to the presence of phosphonium salt II. Upon adding $\mathrm{Et}_{3} \mathrm{~N}$, a signal of $\mathrm{Ph}_{3} \mathrm{P}=\mathrm{O}$ rapidly appeared at 29.16 ppm as a major peak along with some other minor phosphorus species. Unfortunately, the signal arises from phosphonium salt intermediate III could not be observed. This data suggests a rapid conversion of III to IV leading to a release of $\mathrm{Ph}_{3} \mathrm{P}=\mathrm{O}$ at this stage. Addition of hydroxylamine hydrochloride finally led to a complete disappearance of the species I, while the signal of $\mathrm{Ph}_{3} \mathrm{P}=\mathrm{O}$ appeared in a greater amount.

To our delight, when monitoring the reaction between benzoyl chloride and aniline, a signal at $65.38 \mathrm{ppm}$ which could be attributed to the amide phosphonium salt III was detected upon adding $\mathrm{Ph}_{3} \mathrm{P}$ and $\mathrm{I}_{2}$ to the preformed $\mathrm{N}$-phenylbenzamide (Fig. S1, ESI $\dagger$ ). This data is consistent with the observed chemical shift for the nucleoside phosphonium salt $(\delta=66.2$ $\mathrm{ppm}$ ) in the synthesis of $O^{6}$-(benzotriazol-1-yl)inosine nucleosides promoted by the same reagent combination. ${ }^{24}$

To further demonstrate the synthetic application of the developed methodology, the conversion of 2 into 1,2,4-oxadiazol-5(4H)-one 3 was investigated. These structures are known to be valuable heterocycles as amidine precursors ${ }^{25}$ or as bioisosteric replacement for the carboxylic acid, amide or ester. ${ }^{26}$ Additionally, compounds bearing oxadiazolone pharmacophore have been shown to possess a range of pharmacological and biological activities. ${ }^{14 b, 27}$ The reported methods for the preparation of 1,2,4-oxadiazolones from $\mathrm{N}$-substituted 


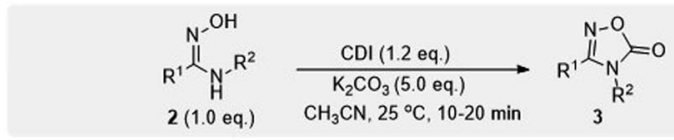

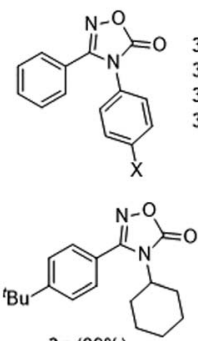

$3 g(89 \%)$

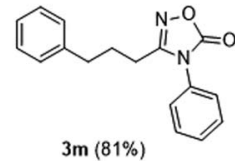

$3 \mathrm{~m}(81 \%)$

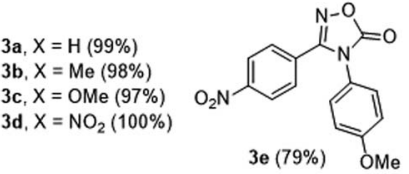

3e $(79 \%)$ OMe

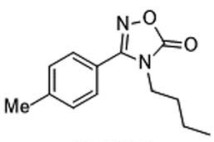

$3 \mathrm{~h}(89 \%)$
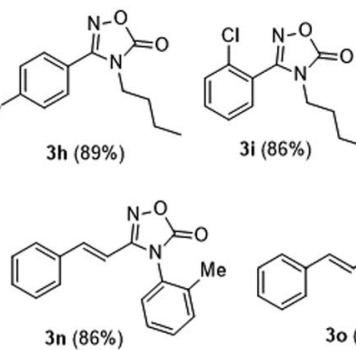

3n $(86 \%)$
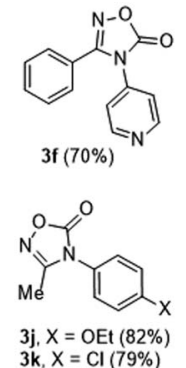
$3 k, X=\mathrm{Cl}(79 \%)$
$3 \mathrm{I}, X=\operatorname{Br}(77 \%)$

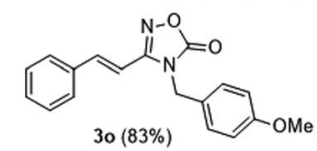

Scheme 5 Synthesis of 1,2,4-oxadiazol-5(4H)-ones 3.

amidoximes often require multiple steps, harsh reaction conditions, and long reaction times. ${ }^{5,14 b, 28}$

Through a screening for the best reaction conditions, it was found that, by treatment of amidoximes 2 with $1,1^{\prime}$-carbonyldiimidazole (CDI) in the presence of finely ground potassium carbonate, carbonylative cyclization proceeded rapidly to afford products 3 in good to excellent yields (Scheme 5). The reaction took place within 10-20 min at room temperature rather than several hours under the reported refluxing conditions. ${ }^{14 b}$ The method is also applicable with a range of amidoxime substrates containing $N$-aryl, $N$-alkyl, and $N$-benzyl groups.

\section{Conclusions}

In summary, we have developed a convenient one-pot approach for the preparation of $\mathrm{N}$-substituted amidoximes from amides, or the requisite acid chlorides, or carboxylic acids. The protocol represents a fast, efficient, and economic alternative to the earlier reported multistep methods. The mild nature of the procedure enables a range of starting materials accessible. One application of amidoximes as building blocks in the synthesis of 1,2,4-oxadiazol-5(4H)-ones via base-mediated carbonylative cyclization has been demonstrated. Further utility of these amidoximes in organic synthesis of other important pharmacophores is anticipated.

\section{Experimental}

\section{General information}

All reagents were purchased from Sigma-Aldrich Co., USA, and used without further purification. Dichloromethane was freshly distilled over $\mathrm{CaH}_{2}$ before use. The reaction was monitored by thin-layer chromatography carried out on silica gel plates $\left(60 \mathrm{~F}_{254}\right.$, MERCK, Germany) and visualized under UV light (254 $\mathrm{nm}$ ). Melting points were determined using Mettler Toledo DSC equipment at a heating rate of $6{ }^{\circ} \mathrm{C} \mathrm{min}^{-1}$ and are uncorrected. NMR spectra were determined using a Bruker AVANCE ${ }^{\text {TM }}$ (400
MHz for ${ }^{1} \mathrm{H}$ ). Chemical shifts were reported in parts per million $(\mathrm{ppm}, \delta$ ) downfield from TMS. High resolution mass spectra (HRMS) were recorded using the LC-DAD-ESI-MS/MS system consisted of a Waters Alliance 2695 LC-DAD and a Q-TOF 2 (quadrupole mass filter-time-of-fiight) mass spectrometer with a Z-spray ES source.

\section{General procedure for the synthesis of amidoximes from amides or acid chloride}

To a solution of iodine $(0.1904 \mathrm{~g}, 0.75 \mathrm{mmol})$ and triphenylphosphine $(0.1967 \mathrm{~g}, 0.75 \mathrm{mmol})$ in dry dichloromethane $(4 \mathrm{~mL})$ was added amide $(0.50 \mathrm{mmol})$, triethylamine $(0.35 \mathrm{~mL}, 2.50$ $\mathrm{mmol})$, and hydroxylamine hydrochloride $(0.0521 \mathrm{~g}, 0.75 \mathrm{mmol})$ at $0{ }^{\circ} \mathrm{C}$. The reaction mixture was then warm up to room temperature and stirred until completion of the reaction (typically within $2 \mathrm{~h}$ ). The crude mixture was concentrated under reduced pressure then purified by column chromatography using $30-70 \%$ ethyl acetate in hexane. For the synthesis of amidoximes from acid chloride, a mixture of acid chloride $(0.50$ $\mathrm{mmol})$, amine $(0.50 \mathrm{mmol})$, and triethylamine $(0.10 \mathrm{~mL}, 0.75$ $\mathrm{mmol})$ in dry dichloromethane $(4 \mathrm{~mL})$ was stirred at $0{ }^{\circ} \mathrm{C}$ to room temperature until complete disappearance of the acid chloride. The in situ generated amide was then subjected to the reaction with hydroxylamine hydrochloride as described above.

\section{General procedure for the synthesis of amidoximes from carboxylic acids}

To a solution of iodine $(0.3807 \mathrm{~g}, 1.5 \mathrm{mmol})$ and triphenylphosphine $(0.3935 \mathrm{~g}, 1.5 \mathrm{mmol})$ in dry dichloromethane $(5 \mathrm{~mL})$ was added in one portion with carboxylic acid derivative $(0.50$ $\mathrm{mmol})$, and amine $(0.50 \mathrm{mmol})$, followed by triethylamine $(0.45$ $\mathrm{mL}, 3.25 \mathrm{mmol})$ at $0{ }^{\circ} \mathrm{C}$. The resulting mixture was continuously stirred at room temperature for $1 \mathrm{~h}$. Hydroxylamine hydrochloride $(0.0521 \mathrm{~g}, 0.75 \mathrm{mmol})$ was then added and the reaction mixture was allowed to stir until completion of the reaction (typically within $2 \mathrm{~h}$ ). The crude mixture was concentrated under reduced pressure then purified by column chromatography using $30-70 \%$ ethyl acetate in hexane.

(Z)- $N^{\prime}$-Hydroxy- $N$-phenylbenzimidamide (2a).$^{29}$ White solid $\left(0.0904 \mathrm{~g}, 85 \%\right.$ yield), $\mathrm{mp} 137-138{ }^{\circ} \mathrm{C}$ (lit. $\left.29 \mathrm{mp} 136{ }^{\circ} \mathrm{C}\right) ; R_{\mathrm{f}} 0.57$ (30\% EtOAc/hexanes); ${ }^{1} \mathrm{H}$ NMR (400 MHz, $\left.\mathrm{CDCl}_{3}\right) \delta 7.45$ (d, $J=$ $7.2 \mathrm{~Hz}, 2 \mathrm{H}), 7.37(\mathrm{t}, J=7.2 \mathrm{~Hz}, 1 \mathrm{H}), 7.33(\mathrm{t}, J=7.2 \mathrm{~Hz}, 2 \mathrm{H}), 7.10(\mathrm{t}$, $J=7.6 \mathrm{~Hz}, 2 \mathrm{H}), 6.92(\mathrm{t}, J=7.6 \mathrm{~Hz}, 1 \mathrm{H}), 6.67(\mathrm{~d}, J=7.6 \mathrm{~Hz}, 2 \mathrm{H})$.

$(Z)-N^{\prime}$-Hydroxy- $N$-( $p$-tolyl)benzimidamide $(2 b){ }^{30}$ White solid (0.0864 g, $76 \%$ yield), $\mathrm{mp} 178-179^{\circ} \mathrm{C}$ (lit. $\left.30 \mathrm{mp} 176-177^{\circ} \mathrm{C}\right) ; R_{\mathrm{f}}$ $0.30\left(20 \%\right.$ EtOAc/hexanes); ${ }^{1} \mathrm{H}$ NMR $\left(400 \mathrm{MHz}, \mathrm{CDCl}_{3}\right) \delta 7.44(\mathrm{~d}$, $J=7.6 \mathrm{~Hz}, 2 \mathrm{H}), 7.35(\mathrm{t}, J=7.6 \mathrm{~Hz}, 1 \mathrm{H}), 7.31(\mathrm{t}, J=7.6 \mathrm{~Hz}, 2 \mathrm{H})$, $6.91(\mathrm{~d}, J=8.0 \mathrm{~Hz}, 2 \mathrm{H}), 6.58(\mathrm{~d}, J=8.0 \mathrm{~Hz}, 2 \mathrm{H}), 2.22(\mathrm{~s}, 3 \mathrm{H})$.

(Z)- $N^{\prime}$-Hydroxy- $N$-(4-methoxyphenyl)benzimidamide $\quad(2 \mathrm{c}) .^{31}$ White solid (0.0913 g, 75\% yield), mp 139-141 ${ }^{\circ} \mathrm{C}$ (lit. $31 \mathrm{mp}$ 154.4-157.2 $\left.{ }^{\circ} \mathrm{C}\right) ; R_{\mathrm{f}} 0.36$ (20\% EtOAc/hexanes); ${ }^{1} \mathrm{H}$ NMR (400 $\left.\mathrm{MHz}, \mathrm{CDCl}_{3}\right) \delta 7.41(\mathrm{~d}, J=7.6 \mathrm{~Hz}, 2 \mathrm{H}), 7.33(\mathrm{t}, J=7.6 \mathrm{~Hz}, 1 \mathrm{H})$, $7.28(\mathrm{t}, J=7.6 \mathrm{~Hz}, 2 \mathrm{H}), 6.66(\mathrm{~s}, 4 \mathrm{H}), 3.71(\mathrm{~s}, 3 \mathrm{H})$.

(Z)- $N$-(4-Bromophenyl)- $N^{\prime}$-hydroxybenzimidamide $\quad(2 \mathrm{~d}) .^{31}$. White solid (0.1126 g, 77\% yield), mp 193-195 ${ }^{\circ} \mathrm{C}$ (lit. $31 \mathrm{mp}$ 192-193.5 $\left.{ }^{\circ} \mathrm{C}\right) ; R_{\mathrm{f}} 0.33$ (20\% EtOAc/hexanes); ${ }^{1} \mathrm{H}$ NMR $(400 \mathrm{MHz}$, 
$\left.\mathrm{CDCl}_{3}\right) \delta 7.37-7.31(\mathrm{~m}, 3 \mathrm{H}), 7.30-7.25(\mathrm{~m}, 2 \mathrm{H}), 7.14(\mathrm{~d}, J=$ $8.8 \mathrm{~Hz}, 2 \mathrm{H}), 6.47$ (d, $J=8.8 \mathrm{~Hz}, 2 \mathrm{H})$.

(Z)- $\boldsymbol{N}^{\prime}$-Hydroxy- $\boldsymbol{N}$-(4-nitrophenyl)benzimidamide (2e). ${ }^{32}$. Yellow solid (0.1032 g, 80\% yield), mp 149-151 ${ }^{\circ} \mathrm{C}$ (lit. $\left.32 \mathrm{mp} 152{ }^{\circ} \mathrm{C}\right) ; R_{\mathrm{f}}$ 0.32 (30\% EtOAc/hexanes); ${ }^{1} \mathrm{H}$ NMR (400 MHz, $\left.\mathrm{CDCl}_{3}\right) \delta 7.99(\mathrm{~d}$, $J=9.2 \mathrm{~Hz}, 2 \mathrm{H}), 7.51-7.45(\mathrm{~m}, 3 \mathrm{H}), 7.41$ (t, $J=7.6 \mathrm{~Hz}, 2 \mathrm{H}), 6.65$ $(\mathrm{d}, J=9.2 \mathrm{~Hz}, 2 \mathrm{H})$.

(Z)- $N^{\prime}$-Hydroxy- $N$-(4-methoxyphenyl)-4-nitrobenzimidamide (2f). ${ }^{32}$ White solid ( $0.0936 \mathrm{~g}$, 65\% yield), mp 160-162 ${ }^{\circ} \mathrm{C}$ (lit. 32 $\mathrm{mp} 163{ }^{\circ} \mathrm{C}$ ); $R_{\mathrm{f}} 0.60$ (40\% EtOAc/hexanes); ${ }^{1} \mathrm{H}$ NMR $(400 \mathrm{MHz}$, $\left.\mathrm{CDCl}_{3}\right) \delta 8.07(\mathrm{~d}, J=8.8 \mathrm{~Hz}, 2 \mathrm{H}), 7.52(\mathrm{~d}, J=8.8 \mathrm{~Hz}, 2 \mathrm{H}), 6.62(\mathrm{~s}$, $4 \mathrm{H}), 3.67$ (s, 3H).

(Z)- $\boldsymbol{N}^{\prime}$-Hydroxy- $\boldsymbol{N}$-(pyridin-4-yl)benzimidamide (2g). White solid ( $0.0558 \mathrm{~g}, 52 \%$ yield), $\mathrm{mp} 225-226{ }^{\circ} \mathrm{C} ; R_{\mathrm{f}} 0.35$ (60\% EtOAc/ hexanes); ${ }^{1} \mathrm{H}$ NMR (400 MHz, $\mathrm{CDCl}_{3}+4$ drops of $\left.\mathrm{CD}_{3} \mathrm{OD}\right) \delta 8.04$ $(\mathrm{d}, J=5.6 \mathrm{~Hz}, 2 \mathrm{H}), 7.39-7.30(\mathrm{~m}, 5 \mathrm{H}), 6.40(\mathrm{~d}, J=5.6 \mathrm{~Hz}, 2 \mathrm{H})$; ${ }^{13} \mathrm{C}$ NMR $\left(100 \mathrm{MHz}, \mathrm{CDCl}_{3}+4\right.$ drops of $\left.\mathrm{CD}_{3} \mathrm{OD}\right) \delta 159.1,149.04$, 147.6, 130.70, 130.19, 128.77, 127.87, 113.23; HRMS (ESI-TOF) $m / z$ : calcd for $\mathrm{C}_{12} \mathrm{H}_{11} \mathrm{~N}_{3} \mathrm{NaO}[\mathrm{M}+\mathrm{Na}]^{+} 236.0800$, found 236.0807.

(Z)- $\boldsymbol{N}$-Butyl- $\boldsymbol{N}^{\prime}$-hydroxy-4-methylbenzimidamide (2h) ${ }^{33}$. Yellow oil ( $0.0845 \mathrm{~g}, 82 \%$ yield); $R_{\mathrm{f}} 0.33$ (30\% EtOAc/hexanes); ${ }^{1} \mathrm{H}$ NMR $\left(400 \mathrm{MHz}, \mathrm{CDCl}_{3}\right) \delta 7.37(\mathrm{~d}, J=8.0 \mathrm{~Hz}, 2 \mathrm{H}), 7.22(\mathrm{~d}, J=8.0 \mathrm{~Hz}$, 2H), 5.26 (br s, 1H), 3.03 (q, $J=7.2 \mathrm{~Hz}, 2 \mathrm{H}), 2.40$ (s, 3H), 1.44 (quin, $J=7.2 \mathrm{~Hz}, 2 \mathrm{H}), 1.32(\mathrm{sex}, J=7.2 \mathrm{~Hz}, 2 \mathrm{H}), 0.87(\mathrm{t}, J=$ $7.2 \mathrm{~Hz}, 3 \mathrm{H})$.

(Z)- $N$-Butyl-2-chloro- $\boldsymbol{N}^{\prime}$-hydroxybenzimidamide (2i). Colorless oil ( $0.0671 \mathrm{~g}, 59 \%$ yield); $R_{\mathrm{f}} 0.45$ (30\% EtOAc/hexanes); ${ }^{1} \mathrm{H}$ NMR (400 MHz, $\mathrm{CDCl}_{3}$ ) $\delta 7.44-7.28$ (m, 4H), 5.39 (brs, 1H), 2.87 (t, $J=7.2 \mathrm{~Hz}, 2 \mathrm{H}$ ), 1.88 (d, $J=10.0 \mathrm{~Hz}, 1 \mathrm{H}$ ), 1.40 (quin, $J=$ $7.2 \mathrm{~Hz}, 2 \mathrm{H}), 1.26$ (sex, $J=7.2 \mathrm{~Hz}, 2 \mathrm{H}), 0.82(\mathrm{t}, J=7.2 \mathrm{~Hz}, 3 \mathrm{H}) ;{ }^{13} \mathrm{C}$ NMR (100 MHz, $\left.\mathrm{CDCl}_{3}\right)$ 153.7, 133.9, 131.47, 130.9, 130.6, 129.6, 126.7, 42.56, 33.0, 19.7, 13.7; HRMS (ESI-TOF) $\mathrm{m} / \mathrm{z}$ : calcd for $\mathrm{C}_{11} \mathrm{H}_{15} \mathrm{ClN}_{2} \mathrm{NaO}[\mathrm{M}+\mathrm{Na}]^{+} 249.0771$, found 249.0774.

(Z)- $\boldsymbol{N}$-(4-Ethoxyphenyl)- $\boldsymbol{N}^{\prime}$-hydroxyacetimidamide (2j). White solid ( $0.0775 \mathrm{~g}, 80 \%$ yield), $\mathrm{mp} 132-134{ }^{\circ} \mathrm{C} ; R_{\mathrm{f}} 0.41$ (40\% EtOAc/ hexanes); ${ }^{1} \mathrm{H}$ NMR (400 MHz, $\left.\mathrm{CDCl}_{3}\right) \delta 7.04(\mathrm{~d}, J=8.8 \mathrm{~Hz}, 2 \mathrm{H})$, $6.86(\mathrm{~d}, J=8.8 \mathrm{~Hz}, 2 \mathrm{H}), 4.03(\mathrm{q}, J=7.2 \mathrm{~Hz}, 2 \mathrm{H}), 1.87(\mathrm{~s}, 3 \mathrm{H}), 1.43$ (t, $J=7.2 \mathrm{~Hz}, 3 \mathrm{H})$.

(Z)- $\boldsymbol{N}$-(4-Chlorophenyl)- $\boldsymbol{N}^{\prime}$-hydroxyacetimidamide (2k). ${ }^{34}$. White solid (0.0695 g, 75\% yield), mp 133-135 ${ }^{\circ} \mathrm{C}$ (lit. $34 \mathrm{mp}$ $\left.132-133{ }^{\circ} \mathrm{C}\right) ; R_{\mathrm{f}} 0.40$ (30\% EtOAc/hexanes); ${ }^{1} \mathrm{H}$ NMR $(400 \mathrm{MHz}$, $\left.\mathrm{CDCl}_{3}\right) \delta 7.31(\mathrm{~d}, J=8.4 \mathrm{~Hz}, 2 \mathrm{H}), 7.02(\mathrm{~d}, J=8.4 \mathrm{~Hz}, 2 \mathrm{H}), 1.97(\mathrm{~s}$, $3 \mathrm{H})$.

(Z)- $\boldsymbol{N}$-(4-Bromophenyl)- $\boldsymbol{N}^{\prime}$-hydroxyacetimidamide (21). ${ }^{18}$. White solid ( $0.0825 \mathrm{~g}, 72 \%$ yield), $\mathrm{mp} 86-87{ }^{\circ} \mathrm{C} ; R_{\mathrm{f}} 0.51$ (30\% EtOAc/ hexanes); ${ }^{1} \mathrm{H}$ NMR (400 MHz, $\left.\mathrm{CDCl}_{3}\right) \delta 7.45(\mathrm{~d}, J=8.4 \mathrm{~Hz}$, $2 \mathrm{H}), 6.96(\mathrm{~d}, J=8.8 \mathrm{~Hz}, 2 \mathrm{H}), 1.99(\mathrm{~s}, 3 \mathrm{H})$.

$(Z)-N^{\prime}$-Hydroxy- $N$-phenylpropionimidamide $\quad(2 \mathrm{~m}) \cdot{ }^{19} \quad$ Yellow oil (0.0553 g, 67\% yield), $R_{\mathrm{f}} 0.35$ (30\% EtOAc/hexanes); ${ }^{1} \mathrm{H}$ NMR $\left(400 \mathrm{MHz}, \mathrm{CDCl}_{3}\right) \delta 7.35(\mathrm{t}, J=8.0 \mathrm{~Hz}, 2 \mathrm{H}), 7.17(\mathrm{t}, J=8.0 \mathrm{~Hz}$, $1 \mathrm{H}), 7.11(\mathrm{~d}, J=8.0 \mathrm{~Hz}, 2 \mathrm{H}), 2.41(\mathrm{q}, J=7.6 \mathrm{~Hz}, 2 \mathrm{H}), 1.05(\mathrm{t}, J=$ $7.6 \mathrm{~Hz}, 3 \mathrm{H})$.

(Z)- $\boldsymbol{N}^{\prime}$-Hydroxy- $\boldsymbol{N}$,2-bis(4-methoxyphenyl)acetimidamide (2n). White solid (0.1158 g, 81\% yield), mp 133-134 ${ }^{\circ} \mathrm{C} ; R_{\mathrm{f}} 0.67$ (40\% EtOAc/hexanes); ${ }^{1} \mathrm{H}$ NMR (400 MHz, $\left.\mathrm{CDCl}_{3}\right) \delta 7.38(\mathrm{~s}, 1 \mathrm{H}), 7.34$ $(\mathrm{d}, J=8.4 \mathrm{~Hz}, 2 \mathrm{H}), 7.25(\mathrm{~d}, J=8.4 \mathrm{~Hz}, 2 \mathrm{H}), 6.92(\mathrm{~d}, J=8.8 \mathrm{~Hz}$, 2H), 6.82 (d, $J=8.8 \mathrm{~Hz}, 2 \mathrm{H}), 3.83$ (s, 3H), 3.77 (s, 3H), 3.64 (s,
$2 \mathrm{H}) ;{ }^{13} \mathrm{C}$ NMR $\left(100 \mathrm{MHz}, \mathrm{CDCl}_{3}\right) \delta$ 169.6, 159.0, 156.5, 130.9, 130.6, 126.6, 121.8, 114.5, 114.0, 55.5, 55.3, 43.6; HRMS (ESITOF) $m / z$ : calcd for $\mathrm{C}_{16} \mathrm{H}_{19} \mathrm{~N}_{2} \mathrm{O}_{3}[\mathrm{M}+\mathrm{H}]^{+}$287.1396, found 287.1398 .

(Z)- $\boldsymbol{N}^{\prime}$-Hydroxy- $\boldsymbol{N}$,4-diphenylbutanimidamide (2o). Yellow oil (0.0819 g, 64\% yield); $R_{\mathrm{f}} 0.36$ (30\% EtOAc/hexanes); ${ }^{1} \mathrm{H}$ NMR $\left(400 \mathrm{MHz}, \mathrm{CDCl}_{3}\right) \delta 7.33(\mathrm{t}, J=7.6 \mathrm{~Hz}, 2 \mathrm{H}), 7.26(\mathrm{t}, J=7.6 \mathrm{~Hz}$, 2H), 7.21-7.17 (m, 2H), 7.11-7.16 (m, 4H), $2.61(\mathrm{t}, J=7.6 \mathrm{~Hz}$, $2 \mathrm{H}), 2.45(\mathrm{t}, J=7.6 \mathrm{~Hz}, 2 \mathrm{H}), 1.80$ (quin, $J=7.6 \mathrm{~Hz}, 2 \mathrm{H}) ;{ }^{13} \mathrm{C} \mathrm{NMR}$ $\left(100 \mathrm{MHz}, \mathrm{CDCl}_{3}\right) \delta 153.0,141.6,138.9,129.2,128.5,128.3$, 125.8, 124.7, 124.2, 35.2, 28.5, 27.7; HRMS (ESI-TOF) $m / z$ : calcd for $\mathrm{C}_{16} \mathrm{H}_{19} \mathrm{~N}_{2} \mathrm{O}[\mathrm{M}+\mathrm{H}]^{+}$255.1497, found 255.1494.

(Z)- $\boldsymbol{N}^{\prime}$-Hydroxy- $\boldsymbol{N}$-(o-tolyl)cinnamimidamide (2p). White solid (0.0909 g, 72\% yield), mp 120-122 ${ }^{\circ} \mathrm{C} ; R_{\mathrm{f}} 0.50$ (30\% EtOAc/ hexanes); ${ }^{1} \mathrm{H}$ NMR (400 MHz, $\left.\mathrm{CDCl}_{3}\right) \delta 7.40-7.30(\mathrm{~m}, 5 \mathrm{H}), 7.22$ $(\mathrm{d}, J=16.0 \mathrm{~Hz}, 1 \mathrm{H}), 7.18-7.05(\mathrm{~m}, 4 \mathrm{H}), 6.48(\mathrm{~d}, J=16.0 \mathrm{~Hz}, 1 \mathrm{H})$, 2.34 (s, 3H); ${ }^{13} \mathrm{C}$ NMR (100 MHz, $\mathrm{CDCl}_{3}$ ) $\delta 150.9,137.7,136.1$, $134.7,131.1,130.8,128.7,128.7,127.1,126.6$, 124.4, 124.0, 117.9, 18.0; HRMS (ESI-TOF) $m / z$ : calcd for $\mathrm{C}_{16} \mathrm{H}_{17} \mathrm{~N}_{2} \mathrm{O}[\mathrm{M}+\mathrm{H}]^{+}$ 253.1341.1916, found 253.1338.

(Z)- $\boldsymbol{N}^{\prime}$-Hydroxy- $\boldsymbol{N}$-(4-methoxybenzyl)cinnamimidamide (2q). Yellow oil ( $0.1073 \mathrm{~g}, 76 \%$ yield); $R_{\mathrm{f}} 0.34$ (30\% EtOAc/hexanes); ${ }^{1} \mathrm{H}$ NMR (400 MHz, $\mathrm{CDCl}_{3}$ ) $\delta$ 7.43-7.40 (m, 2H), 7.36-7.24 (m, $5 \mathrm{H}), 7.20(\mathrm{~d}, J=16.4 \mathrm{~Hz}, 1 \mathrm{H}), 6.89(\mathrm{~d}, J=8.8 \mathrm{~Hz}, 2 \mathrm{H}), 6.53(\mathrm{~d}, J=$ $16.4 \mathrm{~Hz}, 1 \mathrm{H}), 5.61$ (br s, 1H), 4.39 (s, 2H), 3.82 (s, 3H); ${ }^{13} \mathrm{C}$ NMR $\left(100 \mathrm{MHz}, \mathrm{CDCl}_{3}\right) \delta 158.9,153.9,136.0,135.6,131.4,128.7$, 128.2 , 127.1, 116.9, 114.1, 55.3, 46.4; HRMS (ESI-TOF) $\mathrm{m} / \mathrm{z}$ : calcd for $\mathrm{C}_{17} \mathrm{H}_{19} \mathrm{~N}_{2} \mathrm{O}_{2}[\mathrm{M}+\mathrm{H}]^{+}$283.1447, found 283.1454.

$(Z)$ - $N^{\prime}$-Hydroxybenzimidamide $(2 \mathrm{r}) .{ }^{35}$ Colorless oil $(0.0458 \mathrm{~g}$, $67 \%$ yield); $R_{\mathrm{f}} 0.70$ (40\% EtOAc/hexanes); ${ }^{1} \mathrm{H}$ NMR $(400 \mathrm{MHz}$, $\left.\mathrm{CDCl}_{3}\right) \delta 7.62(\mathrm{dd}, J=7.6,1.6 \mathrm{~Hz}, 2 \mathrm{H}), 7.41-7.34(\mathrm{~m}, 3 \mathrm{H}), 4.98(\mathrm{~s}$, $2 \mathrm{H}){ }^{13} \mathrm{C} \mathrm{NMR}\left(100 \mathrm{MHz}, \mathrm{CDCl}_{3}\right) \delta 152.9,132.5,130.0,128.7$, 126.0.

(Z)-4-(tert-Butyl)- $N$-cyclohexyl- $N$-hydroxybenzimidamide (2s). White solid ( $0.0715 \mathrm{~g}, 52 \%$ yield), mp $139-140{ }^{\circ} \mathrm{C} ; R_{\mathrm{f}} 0.36(30 \%$ EtOAc/hexanes); ${ }^{1} \mathrm{H}$ NMR (400 MHz, $\left.\mathrm{CDCl}_{3}\right) \delta 7.41(\mathrm{~s}, 4 \mathrm{H}), 5.21$ (d, $J=10.0 \mathrm{~Hz}, 1 \mathrm{H}), 3.15-3.10$ (m, 1H), 1.85-1.80 (m, 2H), 1.69-1.67 (m, 2H), 1.54-1.51 (m, 1H), 1.35 (s, 9H), 1.20-1.13 (m, 5H).

General procedure for the synthesis of 1,2,4-oxadiazol-5(4H)one

To a solution of $N$-substituted amidoxime $2(0.30 \mathrm{mmol})$ dissolved in acetonitrile $(2.0 \mathrm{~mL})$ was added 1,1'-carbonyldiimidazole $(0.0584 \mathrm{~g}, 0.36 \mathrm{mmol})$, followed by finely grounded $\mathrm{K}_{2} \mathrm{CO}_{3}(0.2073 \mathrm{~g}, 1.50 \mathrm{mmol})$. The resulting mixture was stirred at room temperature for 10-20 min. The crude mixture was concentrated under reduced pressure and then purified by short column chromatography using $10-40 \%$ ethyl acetate in hexane to give the corresponding product.

3,4-Diphenyl-1,2,4-oxadiazol-5(4H)-one (3a). ${ }^{36}$ White solid (0.0707 g, 99\% yield), $\mathrm{mp} 167-168{ }^{\circ} \mathrm{C}$ (lit. $\left.36 \mathrm{mp} 168-169{ }^{\circ} \mathrm{C}\right) ; R_{\mathrm{f}}$ 0.57 (30\% EtOAc/hexanes); ${ }^{1} \mathrm{H}$ NMR (400 MHz, $\left.\mathrm{CDCl}_{3}\right) \delta 7.53-$ $7.45(\mathrm{~m}, 4 \mathrm{H}), 7.40-7.36(\mathrm{~m}, 4 \mathrm{H}), 7.27-7.22$ (m, 2H).

3-Phenyl-4-(p-tolyl)-1,2,4-oxadiazol-5(4H)-one (3b). ${ }^{37}$ White solid ( $0.0742 \mathrm{~g}, 98 \%$ yield), mp $163-164{ }^{\circ} \mathrm{C}$ (lit. $\left.37 \mathrm{mp} 163{ }^{\circ} \mathrm{C}\right) ; R_{\mathrm{f}}$ 0.51 (30\% EtOAc/hexanes); ${ }^{1} \mathrm{H}$ NMR (400 MHz, $\left.\mathrm{CDCl}_{3}\right) \delta 7.53-$ 
7.47 (m, 1H), 7.39 (s, 2H), $7.38(\mathrm{~s}, 2 \mathrm{H}), 7.26(\mathrm{~d}, J=8.0 \mathrm{~Hz}, 2 \mathrm{H})$, $7.13(\mathrm{~d}, J=8.0 \mathrm{~Hz}, 2 \mathrm{H}), 2.41(\mathrm{~s}, 3 \mathrm{H})$.

4-(4-Methoxyphenyl)-3-phenyl-1,2,4-oxadiazol-5(4H)-one (3c). ${ }^{31}$. White solid ( $0.0781 \mathrm{~g}, 97 \%$ yield), mp 161-162 ${ }^{\circ} \mathrm{C}$ (lit. 31 mp 158.1-160.2 $\left.{ }^{\circ} \mathrm{C}\right) ; R_{\mathrm{f}} 0.52$ (30\% EtOAc/hexanes); ${ }^{1} \mathrm{H}$ NMR (400 $\left.\mathrm{MHz} \mathrm{CDCl}_{3}\right) \delta 7.55-7.46(\mathrm{~m}, 1 \mathrm{H}), 7.40(\mathrm{~s}, 2 \mathrm{H}), 7.39(\mathrm{~s}, 2 \mathrm{H}), 7.17$ $(\mathrm{d}, J=8.8 \mathrm{~Hz}, 2 \mathrm{H}), 6.96(\mathrm{~d}, J=8.8 \mathrm{~Hz}, 2 \mathrm{H}), 3.85(\mathrm{~s}, 3 \mathrm{H})$.

4-(4-Nitrophenyl)-3-phenyl-1,2,4-oxadiazol-5(4H)-one $\quad(3 \mathrm{~d}){ }^{32}$ Yellow oil ( $0.0849 \mathrm{~g}, 100 \%$ yield), $R_{\mathrm{f}} 0.44$ (30\% EtOAc/hexanes); ${ }^{1} \mathrm{H} \mathrm{NMR}\left(400 \mathrm{MHz}, \mathrm{CDCl}_{3}\right) \delta 8.31(\mathrm{~d}, J=9.2 \mathrm{~Hz}, 2 \mathrm{H}), 7.60(\mathrm{t}, J=$ $7.6 \mathrm{~Hz}, 1 \mathrm{H}), 7.45(\mathrm{t}, J=7.6 \mathrm{~Hz}, 2 \mathrm{H}), 7.44(\mathrm{~d}, J=9.2 \mathrm{~Hz}, 2 \mathrm{H}), 7.38$ (d, $J=7.6 \mathrm{~Hz}, 2 \mathrm{H})$.

4-(4-Methoxyphenyl)-3-(4-nitrophenyl)-1,2,4-oxadiazol-5(4H)one (3e). ${ }^{32}$. White solid ( $0.0743 \mathrm{~g}, 79 \%$ yield), mp $173-174{ }^{\circ} \mathrm{C} ; R_{\mathrm{f}}$ 0.53 (30\% EtOAc/hexanes); ${ }^{1} \mathrm{H}$ NMR (400 MHz, $\left.\mathrm{CDCl}_{3}\right) \delta 8.25$ (d, $J=8.8 \mathrm{~Hz}, 2 \mathrm{H}), 7.62(\mathrm{~d}, J=8.8 \mathrm{~Hz}, 2 \mathrm{H}), 7.18(\mathrm{~d}, J=8.8 \mathrm{~Hz}, 2 \mathrm{H})$, $6.99(\mathrm{~d}, J=8.8 \mathrm{~Hz}, 2 \mathrm{H}), 3.87$ (s, 3H).

3-Phenyl-4-(pyridin-4-yl)-1,2,4-oxadiazol-5(4H)-one (3f). White solid (0.0503 g, 70\% yield), $\mathrm{mp} 167-168{ }^{\circ} \mathrm{C} ; R_{\mathrm{f}} 0.30$ (40\% EtOAc/ hexanes); ${ }^{1} \mathrm{H}$ NMR $\left(400 \mathrm{MHz}, \mathrm{CDCl}_{3}\right) \delta 8.71(\mathrm{dd}, J=4.4,1.6 \mathrm{~Hz}$, $2 \mathrm{H}), 7.58(\mathrm{t}, J=8.0 \mathrm{~Hz}, 1 \mathrm{H}), 7.46(\mathrm{t}, J=8.0 \mathrm{~Hz}, 2 \mathrm{H}), 7.38(\mathrm{~d}, J=$ $8.0 \mathrm{~Hz}, 2 \mathrm{H}), 7.19(\mathrm{dd}, J=4.4,1.6 \mathrm{~Hz}, 2 \mathrm{H}) ;{ }^{13} \mathrm{C}$ NMR $(100 \mathrm{MHz}$, $\left.\mathrm{CDCl}_{3}\right) \delta 156.8,151.4,139.6,132.5,129.3,128.3,122.4,120.1$; HRMS (ESI-TOF) $m / z$ : calcd for $\mathrm{C}_{13} \mathrm{H}_{9} \mathrm{~N}_{2} \mathrm{NaO}_{2}[\mathrm{M}+\mathrm{Na}]^{+}$ 262.0592, found 262.0589 .

3-(4-(tert-Butyl)phenyl)-4-cyclohexyl-1,2,4-oxadiazol-5(4H)one (3g). White solid $(0.0803 \mathrm{~g}, 89 \%$ yield $)$, mp $172-173{ }^{\circ} \mathrm{C} ; R_{\mathrm{f}}$ 0.36 (30\% EtOAc/hexanes); ${ }^{1} \mathrm{H}$ NMR (400 MHz, $\left.\mathrm{CDCl}_{3}\right) \delta 7.59(\mathrm{~d}$, $J=8.4 \mathrm{~Hz}, 2 \mathrm{H}), 7.45$ (d, $J=8.4 \mathrm{~Hz}, 2 \mathrm{H}), 3.75-3.60$ (m, 1H), 2.412.17 (m, 2H), 1.89-1.85 (m, 2H), 1.82-1.76 (m, 2H), 1.66-1.63 $(\mathrm{m}, 2 \mathrm{H}), 1.39$ (s, 9H), 1.29-1.20 (s, 2H); ${ }^{13} \mathrm{C}$ NMR $(100 \mathrm{MHz}$, $\left.\mathrm{CDCl}_{3}\right) \delta 159.2,158.7,155.5,128.4,126.3,120.5,55.4,35.1,31.1$, 29.2 2 25.5, 24.5; HRMS (ESI-TOF) $m / z$ : calcd for $\mathrm{C}_{18} \mathrm{H}_{25} \mathrm{~N}_{2} \mathrm{O}_{2}[\mathrm{M}+$ $\mathrm{H}]^{+}$301.1916, found 301.1923.

4-Butyl-3-(p-tolyl)-1,2,4-oxadiazol-5(4H)-one (3h). Yellow oil (0.0621 g, 89\% yield), $R_{\mathrm{f}} 0.49$ (20\% EtOAc/hexanes); ${ }^{1} \mathrm{H}$ NMR $\left(400 \mathrm{MHz}, \mathrm{CDCl}_{3}\right) \delta 7.47(\mathrm{~d}, J=8.0 \mathrm{~Hz}, 2 \mathrm{H}), 7.37(\mathrm{~d}, J=8.0 \mathrm{~Hz}$, $2 \mathrm{H}$ ), $3.68(\mathrm{t}, J=7.6 \mathrm{~Hz}, 2 \mathrm{H}), 2.47(\mathrm{~s}, 3 \mathrm{H}), 1.60$ (quin, $J=4.4 \mathrm{~Hz}$, $2 \mathrm{H}$ ), 1.27 (sex, $J=7.6 \mathrm{~Hz}, 2 \mathrm{H}), 0.87$ (t, $J=7.6 \mathrm{~Hz}, 3 \mathrm{H}$ ); ${ }^{13} \mathrm{C} \mathrm{NMR}$ $\left(100 \mathrm{MHz} \mathrm{CDCl}_{3}\right) \delta 158.9,152.9,142.6,130.1,128.1,120.6,42.8$, 30.4, 21.6, 19.5, 13.4; HRMS (ESI-TOF) $m / z$ : calcd for $\mathrm{C}_{13} \mathrm{H}_{17} \mathrm{~N}_{2} \mathrm{O}_{2}$ $[\mathrm{M}+\mathrm{H}]^{+}$233.1290, found 233.1286.

4-Butyl-3-(2-chlorophenyl)-1,2,4-oxadiazol-5(4H)-one (3i). Colorless oil ( $0.0654 \mathrm{~g}, 86 \%$ yield), $R_{\mathrm{f}} 0.43$ (20\% EtOAc/hexanes); ${ }^{1} \mathrm{H}$ NMR (400 MHz, $\left.\mathrm{CDCl}_{3}\right) \delta$ 7.63-7.57 (m, 2H), 7.51-7.46 (m, $2 \mathrm{H}$ ), $3.52(\mathrm{t}, J=7.6 \mathrm{~Hz}, 2 \mathrm{H}), 1.50$ (quin, $J=7.6 \mathrm{~Hz}, 2 \mathrm{H}$ ), 1.20 (sex, $J=7.6 \mathrm{~Hz}, 2 \mathrm{H}), 0.79(\mathrm{t}, J=7.6 \mathrm{~Hz}, 3 \mathrm{H}) ;{ }^{13} \mathrm{C} \mathrm{NMR}(100 \mathrm{MHz}$, $\left.\mathrm{CDCl}_{3}\right) \delta 159.1,157.3,134.0,133.4,131.7,130.4,127.6,123.1$, 42.8, 30.0, 19.4, 13.3; HRMS (ESI-TOF) $m / z$ : calcd for $\mathrm{C}_{12} \mathrm{H}_{13}{ }^{35} \mathrm{Cl}$ $\mathrm{N}_{2} \mathrm{NaO}_{2}[\mathrm{M}+\mathrm{Na}]^{+} 275.0563$, found 275.0560 , for $\mathrm{C}_{12} \mathrm{H}_{13}{ }^{37-}$ $\mathrm{ClN}_{2} \mathrm{NaO}_{2}[\mathrm{M}+\mathrm{Na}]^{+}$277.0533, found 277.0536.

4-(4-Ethoxyphenyl)-3-methyl-1,2,4-oxadiazol-5(4H)-one (3j). White solid (0.0544 g, 82\% yield), $\mathrm{mp} 83.7-84.2^{\circ} \mathrm{C} ; R_{\mathrm{f}} 0.50(30 \%$ EtOAc/hexanes); ${ }^{1} \mathrm{H}$ NMR $\left(400 \mathrm{MHz}, \mathrm{CDCl}_{3}\right) \delta 7.21(\mathrm{~d}, J=8.4 \mathrm{~Hz}$, $2 \mathrm{H}), 7.01(\mathrm{~d}, J=8.4 \mathrm{~Hz}, 2 \mathrm{H}), 4.08(\mathrm{q}, J=7.2 \mathrm{~Hz}, 2 \mathrm{H}), 2.15(\mathrm{~s}, 3 \mathrm{H})$, $1.45(\mathrm{t}, J=7.2 \mathrm{~Hz}, 3 \mathrm{H}) ;{ }^{13} \mathrm{C} \mathrm{NMR}\left(100 \mathrm{MHz}, \mathrm{CDCl}_{3}\right) \delta 160.0$, 158.4, 156.6, 128.1, 123.3, 115.7, 64.0, 14.7, 11.0; HRMS (ESI-
TOF) $m / z$ : calcd for $\mathrm{C}_{11} \mathrm{H}_{13} \mathrm{~N}_{2} \mathrm{O}_{3}[\mathrm{M}+\mathrm{H}]^{+}$221.0926, found 221.0929 .

4-(4-Chlorophenyl)-3-methyl-1,2,4-oxadiazol-5(4H)-one (3k). White solid (0.0501 g, 79\% yield), mp 137-138 ${ }^{\circ} \mathrm{C} ; R_{\mathrm{f}} 0.49(30 \%$ EtOAc/hexanes); ${ }^{1} \mathrm{H}$ NMR (400 MHz, $\left.\mathrm{CDCl}_{3}\right) \delta 7.52(\mathrm{~d}, J=8.8 \mathrm{~Hz}$, $2 \mathrm{H}), 7.30(\mathrm{~d}, J=8.8 \mathrm{~Hz}, 2 \mathrm{H}), 2.19(\mathrm{~s}, 3 \mathrm{H}) ;{ }^{13} \mathrm{C}$ NMR $(100 \mathrm{MHz}$, $\left.\mathrm{CDCl}_{3}\right) \delta$ 157.7, 156.0, 136.0, 130.4, 129.6, 128.0, 11.1; HRMS (ESI-TOF) $m / z$ : calcd for $\mathrm{C}_{9} \mathrm{H}_{7}{ }^{35} \mathrm{Cl} \mathrm{N}_{2} \mathrm{NaO}_{2}[\mathrm{M}+\mathrm{Na}]^{+}$233.0094, found 233.0088, for $\mathrm{C}_{9} \mathrm{H}_{7}{ }^{37} \mathrm{ClN}_{2} \mathrm{NaO}_{2}[\mathrm{M}+\mathrm{Na}]^{+}$235.0064, found 235.0061 .

4-(4-Bromophenyl)-3-methyl-1,2,4-oxadiazol-5(4H)-one (31). White solid (0.0591 g, 77\% yield), mp 160-162 ${ }^{\circ} \mathrm{C} ; R_{\mathrm{f}} 0.35(30 \%$ EtOAc/hexanes); ${ }^{1} \mathrm{H}$ NMR (400 MHz, $\left.\mathrm{CDCl}_{3}\right) \delta 7.68(\mathrm{~d}, J=8.4 \mathrm{~Hz}$, $2 \mathrm{H}), 7.23(\mathrm{~d}, J=8.4 \mathrm{~Hz}, 2 \mathrm{H}), 2.20(\mathrm{~s}, 3 \mathrm{H}) ;{ }^{13} \mathrm{C}$ NMR $(100 \mathrm{MHz}$, $\left.\mathrm{CDCl}_{3}\right) \delta 157.7,155.8,133.4,130.1,128.2$, 124.1, 11.1; HRMS (ESI-TOF) $m / z$ : calcd for $\mathrm{C}_{9} \mathrm{H}_{7}{ }^{79} \mathrm{Br} \mathrm{N}_{2} \mathrm{NaO}_{2}[\mathrm{M}+\mathrm{Na}]^{+}$276.9589, found 276.9586, for $\mathrm{C}_{9} \mathrm{H}_{7}{ }^{81} \mathrm{BrN}_{2} \mathrm{NaO}_{2}[\mathrm{M}+\mathrm{Na}]^{+} 278.9569$, found 278.9564 .

4-Phenyl-3-(3-phenylpropyl)-1,2,4-oxadiazol-5(4H)-one (3m). Yellow oil ( $0.0683 \mathrm{~g}, 81 \%$ yield); $R_{\mathrm{f}} 0.37$ (30\% EtOAc/hexanes); ${ }^{1} \mathrm{H}$ NMR (400 MHz, $\mathrm{CDCl}_{3}$ ) $\delta$ 7.55-7.51 (m, 3H), 7.29-7.21 (m, $5 \mathrm{H}), 7.22(\mathrm{~d}, J=7.2 \mathrm{~Hz}, 1 \mathrm{H}), 7.07(\mathrm{~d}, J=7.2 \mathrm{~Hz}, 2 \mathrm{H}), 2.66(\mathrm{t}, J=$ $7.6 \mathrm{~Hz}, 2 \mathrm{H}$ ), 2.51 (t, $J=7.6 \mathrm{~Hz}, 2 \mathrm{H}$ ), 1.91 (quin, $J=7.6 \mathrm{~Hz}, 2 \mathrm{H}$ ); ${ }^{13} \mathrm{C}$ NMR (100 MHz, $\left.\mathrm{CDCl}_{3}\right) \delta 158.8,154.1,140.2,131.1,130.1$, 130.0, 128.5, 128.4, 126.8, 126.3, 34.6, 26.0, 24.4; HRMS (ESITOF) $m / z$ : calcd for $\mathrm{C}_{17} \mathrm{H}_{17} \mathrm{~N}_{2} \mathrm{O}_{2}[\mathrm{M}+\mathrm{H}]^{+}$281.1290, found 281.1287 .

(E)-3-Styryl-4-(o-tolyl)-1,2,4-oxadiazol-5(4H)-one (3n). Colorless oil ( $0.0720 \mathrm{~g}, 86 \%$ yield), $R_{\mathrm{f}} 0.60$ (30\% EtOAc/hexanes); ${ }^{1} \mathrm{H}$ NMR $\left(400 \mathrm{MHz}, \mathrm{CDCl}_{3}\right) \delta 7.51(\mathrm{t}, J=7.2 \mathrm{~Hz}, 1 \mathrm{H}), 7.45-7.33(\mathrm{~m}$, $7 \mathrm{H}), 7.29(\mathrm{~d}, J=7.2 \mathrm{~Hz}, 1 \mathrm{H}), 6.28(\mathrm{~d}, J=16.4 \mathrm{~Hz}, 1 \mathrm{H}), 2.29(\mathrm{~s}$, $3 \mathrm{H}) ;{ }^{13} \mathrm{C}$ NMR $\left(100 \mathrm{MHz}, \mathrm{CDCl}_{3}\right) \delta 157.9,156.1,139.9,136.7$, $134.1,131.9,130.8,130.5,130.1,129.0,128.5,127.8,127.6$, 108.1, 17.6; HRMS (ESI-TOF) $m / z$ : calcd for $\mathrm{C}_{17} \mathrm{H}_{15} \mathrm{~N}_{2} \mathrm{O}_{2}[\mathrm{M}+\mathrm{H}]^{+}$ 279.1134 , found 279.1129 .

(E)-4-(4-Methoxybenzyl)-3-styryl-1,2,4-oxadiazol-5(4H)-one (3o). White solid (0.0771 g, 83\% yield), mp $113-114{ }^{\circ} \mathrm{C} ; R_{\mathrm{f}} 0.47$ (30\% EtOAc/hexanes); ${ }^{1} \mathrm{H}$ NMR $\left(400 \mathrm{MHz}, \mathrm{CDCl}_{3}\right) \delta 7.55$ (d, $J=$ $16.0 \mathrm{~Hz}, 1 \mathrm{H}), 7.47-7.40(\mathrm{~m}, 5 \mathrm{H}), 7.27$ (d, $J=8.8 \mathrm{~Hz}, 2 \mathrm{H}), 6.93$ (d, $J=8.8 \mathrm{~Hz}, 2 \mathrm{H}), 6.45(\mathrm{~d}, J=16.0 \mathrm{~Hz}, 1 \mathrm{H}), 4.84(\mathrm{~s}, 2 \mathrm{H}), 3.82(\mathrm{~s}$, $3 \mathrm{H}) ;{ }^{13} \mathrm{C} \mathrm{NMR}\left(100 \mathrm{MHz}, \mathrm{CDCl}_{3}\right) \delta 159.9,156.5,140.5,134.2$, 130.5, 129.2, 129.1, 128.8, 127.6, 126.3, 114.7, 107.5, 55.4, 45.5; HRMS (ESI-TOF) $m / z$ : calcd for $\mathrm{C}_{18} \mathrm{H}_{16} \mathrm{~N}_{2} \mathrm{NaO}_{3}[\mathrm{M}+\mathrm{Na}]^{+}$ 331.1059, found 331.1053.

\section{Conflicts of interest}

There are no conflicts to declare.

\section{Acknowledgements}

Financial support from The Thailand Research Fund through the Royal Golden Jubilee PhD Program to C. D. (Grant No. PHD/ 0086/2557) and N. W. (Grant No. PHD/0072/2559) are gratefully acknowledged. This research work was also partially supported by Chiang Mai University. Special appreciation to Chulabhorn Research Institute (CRI), Thailand for the ESI-MS analysis. 


\section{Notes and references}

1 (a) Y. Yamamoto, T. Tsuritani and T. Mase, Tetrahedron Lett., 2008, 49, 876; (b) A.-A. Gaber and L. Taib, J. Chem. Sci., 2016, 128, 745; (c) F. Risitano, G. Grassi, F. Foti and F. Caruso, J. Chem. Res., Synop., 1983, 52.

2 S. S. Patil, P. C. Mhaske, S. V. Patil and V. D. Bobade, J. Heterocycl. Chem., 2011, 48, 652.

3 K. Muralirajan, R. Kuppusamy, S. Prakash and C. H. Cheng, Adv. Synth. Catal., 2016, 358, 774.

4 (a) F.-L. Zhang, Y.-F. Wang and S. Chiba, Org. Biomol. Chem., 2013, 11, 6003; (b) P. D. Parker and J. G. Pierce, Synthesis, 2016, 48, 1902; (c) S. V. Bhat, D. Robinson, J. E. Moses and P. Sharma, Org. Lett., 2016, 18, 1100; (d) J. J. Lade, B. N. Patil, K. S. Vadagaonkar and A. C. Chaskar, Tetrahedron Lett., 2017, 58, 2103.

5 (a) Y. Durust, C. Altug and F. Kilic, Phosphorus, Sulfur Silicon Relat. Elem., 2007, 182, 299; (b) T. Gerfaud, H.-L. Wei, L. Neuville and J. Zhu, Org. Lett., 2011, 13, 6172; (c) Y. S. Kara, Spectrochim. Acta, Part A, 2015, 149, 920.

6 (a) K. C. Fylaktakidou, D. J. Hadjipavlou-Litina, K. E. Litinas, E. A. Varella and D. N. Nicolaides, Curr. Pharm. Des., 2008, 14, 1001; (b) U. S. Mahajan, R. R. Godinde and P. N. Mandhare, Synth. Commun., 2011, 41, 2195; (c) J. Oszczapowicz, Basicity, H-bonding, tautomerism and complex formation of imidic acid derivatives, Wiley, 1991, vol. 2, p. 623.

7 E. W. Yue, R. Sparks, P. Polam, D. Modi, B. Douty, B. Wayland, B. Glass, A. Takvorian, J. Glenn, W. Zhu, M. Bower, X. Liu, L. Leffet, Q. Wang, K. J. Bowman, M. J. Hansbury, M. Wei, Y. Li, R. Wynn, T. C. Burn, H. K. Koblish, J. S. Fridman, T. Emm, P. A. Scherle, B. Metcalf and A. P. Combs, ACS Med. Chem. Lett., 2017, 8, 486.

8 E. W. Yue, B. Douty, B. Wayland, M. Bower, X. Liu, L. Leffet, Q. Wang, K. J. Bowman, M. J. Hansbury, C. Liu, M. Wei, Y. Li, R. Wynn, T. C. Burn, H. K. Koblish, J. S. Fridman, B. Metcalf, P. A. Scherle and A. P. Combs, J. Med. Chem., 2009, 52, 7364.

9 (a) I. Artsimovitch, C. Chu, A. S. Lynch and R. Landick, Science, 2003, 302, 650; (b) W. Zhu, J. Haupenthal, M. Groh, M. Fountain and R. W. Hartmann, Antimicrob. Agents Chemother., 2014, 58, 4242.

10 D. Schade, J. Kotthaus, L. Riebling, J. Kotthaus, H. MuellerFielitz, W. Raasch, O. Koch, N. Seidel, M. Schmidtke and B. Clement, J. Med. Chem., 2014, 57, 759.

11 (a) F. Fang, J. Zhang, L. Cao, S. Shen, Y. Guo, Z. He and H. Hu, Tetrahedron, 2016, 72, 2476; (b) J. Hu, Z. Li, X. Zhang, Y. Han, Y. Liu, Y. Zhao, Y. Liu and P. Gong, Org. Lett., 2018, 20, 2116; (c) C.-C. Lin, T.-H. Hsieh, P.-Y. Liao, Z.-Y. Liao, C.-W. Chang, Y.-C. Shih, W.-H. Yeh and T.-C. Chien, Org. Lett., 2014, 16, 892; (d) D. Gennet, S. Z. Zard and H. Zhang, Chem. Commun., 2003, 1870; (e) K. W. J. Baker, K. S. Horner, S. A. Moggach, R. M. Paton and I. A. S. Smellie, Tetrahedron Lett., 2004, 45, 8913; (f) S. Zaman, K. Mitsuru and A. D. Abell, Org. Lett., 2005, 7, 609.
12 F. Himo, T. Lovell, R. Hilgraf, V. V. Rostovtsev, L. Noodleman, K. B. Sharpless and V. V. Fokin, J. Am. Chem. Soc., 2005, 127, 210.

13 D. F. Bushey and F. C. Hoover, J. Org. Chem., 1980, 45, 4198. 14 (a) H. C. Shen, F.-X. Ding, Q. Deng, S. Xu, X. Tong, X. Zhang, Y. Chen, G. Zhou, L.-Y. Pai, M. Alonso-Galicia, S. Roy, B. Zhang, J. R. Tata, J. P. Berger and S. L. Colletti, Bioorg. Med. Chem. Lett., 2009, 19, 5716; (b) J. L. Romine, S. W. Martin, V. K. Gribkoff, C. G. Boissard, S. I. Dworetzky, J. Natale, Y. Li, Q. Gao, N. A. Meanwell and J. E. Starrett Jr, J. Med. Chem., 2002, 45, 2942.

15 (a) B. Ganem, Y. Dong, Y. F. Zheng and G. D. Prestwich, J. Org. Chem., 1999, 64, 5441; (b) A. Okano, R. C. James, J. G. Pierce, J. Xie and D. L. Boger, J. Am. Chem. Soc., 2012, 134, 8790.

16 A. R. Katritzky, N. M. Khashab, N. Kirichenko and A. Singh, J. Org. Chem., 2006, 71, 9051.

17 (a) G. D'Alo and P. Grunanger, Farmaco, Ed. Sci., 1966, 21, 346; (b) K. Fang, G. Dong, Y. Li, S. He, Y. Wu, S. Wu, W. Wang and C. Sheng, ACS Med. Chem. Lett., 2018, 9, 312.

18 A. V. Aksenov, A. N. Smirnov, N. A. Aksenov, A. S. Bijieva, I. V. Aksenova and M. Rubin, Org. Biomol. Chem., 2015, 13, 4289.

19 G. Sanguineti, H. V. Le and B. Ganem, Tetrahedron, 2011, 67, 10208.

20 (a) F. C. Kuepper, M. C. Feiters, B. Olofsson, T. Kaiho, S. Yanagida, M. B. Zimmermann, L. J. Carpenter, G. W. Luther, Z. Lu, M. Jonsson and L. Kloo, Angew. Chem., Int. Ed., 2011, 50, 11598; (b) S. U. Tekale, S. S. Kauthale, S. A. Dake, S. R. Sarda and R. P. Pawar, Curr. Org. Chem., 2012, 16, 1485; (c) H. Togo and S. Iida, Synlett, 2006, 2159.

21 J.-R. Dormoy and B. Castro, Triphenylphosphine-Iodine, Encyclopedia of Reagents for Organic Synthesis, John Wiley \& Sons, Ltd, 2009, DOI: 10.1002/047084289X.rt376.pub2.

22 (a) W. Phakhodee, S. Wangngae and M. Pattarawarapan, J. Org. Chem., 2017, 82, 8058; (b) W. Phakhodee, S. Wangngae, N. Wiriya and M. Pattarawarapan, Tetrahedron Lett., 2016, 57, 5351; (c) S. Wangngae, M. Pattarawarapan and W. Phakhodee, Synlett, 2016, 27, 1121; (d) S. Wangngae, M. Pattarawarapan and W. Phakhodee, J. Org. Chem., 2017, 82, 10331; (e) S. Wetosot, W. Phakhodee and M. Pattarawarapan, J. Org. Chem., 2017, 82, 9923.

23 S. Wangngae, C. Duangkamol, M. Pattarawarapan and W. Phakhodee, RSC Adv., 2015, 5, 25789.

24 S. Bae and M. K. Lakshman, J. Org. Chem., 2008, 73, 1311. 25 R. E. Bolton, S. J. Coote, H. Finch, A. Lowdon, N. Pegg and M. V. Vinader, Tetrahedron Lett., 1995, 36, 4471.

26 (a) J. E. Mangette, M. R. Johnson, V.-D. Le, R. A. Shenoy, H. Roark, M. Stier, T. Belliotti, T. Capiris and P. R. Guzzo, Tetrahedron, 2009, 65, 9536; (b) D. J. Wustrow, T. R. Belliotti, T. Capiris, C. O. Kneen, J. S. Bryans, M. J. Field, D. Williams, A. El-Kattan, L. Buchholz, J. J. Kinsora, S. M. Lotarski, M. G. Vartanian, C. P. Taylor, S. D. Donevan, A. J. Thorpe and J. B. Schwarz, Bioorg. Med. Chem. Lett., 2009, 19, 247; (c) G. D. Diana, D. L. Volkots, T. J. Nitz, T. R. Bailey, M. A. Long, N. Vescio, S. Aldous, 
D. C. Pevear and F. J. Dutko, J. Med. Chem., 1994, 37, 2421; (d) M. von Wantoch Rekowski, A. Pyriochou, N. Papapetropoulos, A. Stoessel, A. Papapetropoulos and A. Giannis, Bioorg. Med. Chem., 2010, 18, 1288.

27 (a) R. Budriesi, B. Cosimelli, P. Ioan, C. Z. Lanza, D. Spinelli and A. Chiarini, J. Med. Chem., 2002, 45, 3475; (b) E. Carosati, B. Cosimelli, P. Ioan, E. Severi, K. Katneni, F. C. K. Chiu, S. Saponara, F. Fusi, M. Frosini, R. Matucci, M. Micucci, A. Chiarini, D. Spinelli and R. Budriesi, J. Med. Chem., 2016, 59, 3340; (c) D. N. Nicolaides, K. C. Fylaktakidou, K. E. Litinas and D. Hadjipavlou-Litina, Eur. J. Med. Chem., 1998, 33, 715.

28 (a) T. L. Gilchrist, C. J. Moody and C. W. Rees, J. Chem. Soc., Perkin Trans. 1, 1979, 1871; (b) R. Un and D. Sumengen, Chim. Acta Turc., 1976, 4, 131; (c) H. Bartsch, T. Erker and G. Neubauer, Monatsh. Chem., 1987, 120, 81.

29 F. Minisci, R. Galli and A. Quilico, Tetrahedron Lett., 1963, 4, 785.
30 A. E.-A. M. Gaber and H. McNab, J. Anal. Appl. Pyrolysis, 2009, 86, 369.

31 Y. S. Kara, Spectrochim. Acta, Part A, 2015, 149, 920.

32 T. Bacchetti and A. Alemagna, Atti Accad. Naz. Lincei, Cl. Sci. Fis., Mat. Nat., Rend., 1960, 28, 824.

33 C.-C. Lin, T.-H. Hsieh, P.-Y. Liao, Z.-Y. Liao, C.-W. Chang, Y.-C. Shih, W.-H. Yeh and T.-C. Chien, Org. Lett., 2014, 16, 892.

34 A. Renodon-Cornière, S. Dijols, C. Perollier, D. LefevreGroboillot, J.-L. Boucher, R. Attias, M.-A. Sari, D. Stuehr and D. Mansuy, J. Med. Chem., 2002, 45, 944.

35 J. K. Augustine, V. Akabote, S. G. Hegde and P. Alagarsamy, J. Org. Chem., 2009, 74, 5640.

36 M. W. Partridge and H. A. Turner, J. Chem. Soc., 1958, 2086. 37 H. Ağirbaș and Y. Kara, Phosphorus, Sulfur Silicon Relat. Elem., 2004, 179, 1435. 